\title{
Is Vitamin D Receptor Gene (VDR) Polymorphism TAQ-I Effect the Occurrence and Subtype of Hashimoto's Thyroiditis?
}

\author{
•Fulya Akin ${ }^{1}$ Bedia Guleryuz ${ }^{2}$, Sebahat Turgut ${ }^{3}$, Senay Topsakal' ${ }^{1}$, Guzin Fidan Yaylali ${ }^{1}$, Melek Tunç Ata ${ }^{3}$, Mukaddes Mergen Dalyanoglu ${ }^{3}$ \\ ${ }^{1}$ Department of Endocrinology and Metabolism, ${ }^{2}$ Department of Internal Medicine, ${ }^{3}$ Department of Physiology, Faculty of Medicine, Pamukkale University,
}

Kinikli Campus, Denizli, 20070, Turkey

Objectives:

Hashimoto Thyroiditis (HT) is one of the most common autoimmune thyroiditis that characterized by lymphocytic infiltration (1). More than 30 gene polymorphisms are found in VDR gene. There are studies that reported the relation between Vitamin D levels, VDR and HT. The most common 4 types of polymorphisms studied in autoimmune disease are FOK-I (ekzon 2), BSM-1 (intron 8), APA-1 (intron 8) and TAQ-I (ekzon 9)(2,3). The aim of this study is to investigate the association between VDR TAQ-I gene polymorphism and HT.

\section{Methods:}

We performed a case-control study that included 139 cases with HT (50 euthyroid, 50 subclinical hypothyroid, 39 overt hypothyroid patients) and 50 healthy control. Subjects were recruited from Endocrinology Clinic. VDR TAQ-I gene polymorphisms were examined using a polymerase chain reaction (PCR). Genetic analysis for VDR TaqI gene polymorphisms were done by examined using a polymerase chain reaction (PCR). ). HT cases were classified into three subgroups according to their thyroid function status: Euthyroid patients (Group-1),subclinical hypothyroid patients (group-2) Evident hypothyroid patients (Group-3).

\begin{tabular}{|c|c|c|c|c|}
\hline & $\begin{array}{l}\text { EUTHYROID HT } \\
\text { (GROUP-1) } \\
\text { n(\%) }\end{array}$ & $\begin{array}{l}\text { SUBCLINICAL HT } \\
\text { (GROUP-2) } \\
\text { n(\%) }\end{array}$ & $\begin{array}{c}\text { EVIDENT HT } \\
\text { (GROUP-3) } \\
\text { n(\%) }\end{array}$ & $\begin{array}{c}\text { CONTROL } \\
\text { n(\%) }\end{array}$ \\
\hline \multicolumn{5}{|c|}{ TAQ-I } \\
\hline TT & $23(46.9)$ & $27(55.1)$ & $12(31.6)$ & $17(34)$ \\
\hline $\mathbf{T t}$ & $16(32.7)$ & $19(38.8)$ & $21(53.3)$ & $19(38)$ \\
\hline $\mathbf{t t}$ & $10(20.4)$ & $3(6.1)$ & $5(13.2)$ & $28(14)$ \\
\hline
\end{tabular}

\section{Results:}

In euthyroid group and subclinical hypothyroidism group TT genotype, in the evident hypothyroidism groups and the control group $\mathrm{Tt}$ genotype was detected at the highest rate. (Tabel-1) Statistically significant differences were observed when all Hashimoto's thyroiditis group compared with the control group according to TAQ-I genotype distribution

Conclusions:

VDR gene polymorphisms and vitamin D levels have been associated with various autoimmune diseases.Ramos and colleagues worked VDR BsmI and TaqI gene polymorphism in autoimmune thyroid disease and they showed that gene polymorphism did not affect the development of autoimmune thyroid disease, unlike our study.(4) In the study by Feng et al, they found a significant correlation between the BsmI and TaqI with autoimmune thyroid disease development, there was no significant relationship with FokI and ApaI. (5)

There is relationship between VDR TAQ-I gene polymorphism and Hashimoto's Thyroiditis. This study showed that VDR TAQ-I gene polymorphism may be predisposed to the HT occurrence.

1.F.Baeke, T.Takiishi, H.Korf, C.Gysemans, C.Mathieu, Vitamin D: modulator of the immune system. Curr.Opin. Pharmacol.10(4), 482-496 (2010)

2.A.L.Ponsonby, A.Pezie, J.Ellis, R.Marley ,F.Cameron, J.Carlin, T.Dwyer, Variation in associations between allelie variants of the vitamin d receptor gene and onset of type 1 diabetes mellitus by ambient winter ultraviolet radiation levels: a meta regression analysis. Am.J.Epidemiol 168(4), 358-365(2008)

3. Yazici D, Yavuz D, Tarcin O, Sancak S, Deyneli O, Akalin S.Vitamin D receptor gene ApaI, TaqI, FokI and BsmI polymorphisms in a group of Turkish patients with Hashimoto's thyroiditis.MinervaEndocrinol. 2013 Jun;38(2):195-201

4. Ramos-Lopez E, Kurylowicz A, Bednarczuk T, Paunkovic J, Seidl C, Badenhoop K. Vitamin D receptor polymorphisms are associated with Graves' disease in Germanand Polish but not in Serbian patients. Thyroid. 2005 Oct;15(10):1125-30

5.Ming Feng, HuaLi, Su-FangChen, Wei-FangLi, Fang-Bin Zhang.Polymorphisms in the vitamin D receptor gene and risk of autoimmune thyroid diseases : a meta-analysis Endocrine (2013) 43:318-326 